Retraction

\title{
Retracted: The Effects of Cytokines in Adipose Stem Cell-Conditioned Medium on the Migration and Proliferation of Skin Fibroblasts In Vitro
}

\author{
BioMed Research International \\ Received 25 August 2020; Accepted 25 August 2020; Published 31 October 2020 \\ Copyright (c) 2020 BioMed Research International. This is an open access article distributed under the Creative Commons \\ Attribution License, which permits unrestricted use, distribution, and reproduction in any medium, provided the original work \\ is properly cited.
}

BioMed Research International has retracted the article titled "The Effects of Cytokines in Adipose Stem CellConditioned Medium on the Migration and Proliferation of Skin Fibroblasts In Vitro" [1]. The article is one of four other articles [2-5] published by the same group of authors in 2012 and 2013. It was found to contain duplicated figures and data, where some of the cytokine expression data presented in Table 1 of [1] are repeated in Table 3 of [2], Table 1 of [4], and Table 1 of [5]. Details of the figure duplication are as follows:

a. Figure $1 \mathrm{~d}$ in [1] is the same as Figure $2(\mathrm{a} 1-\mathrm{a} 4)$ in [2] and Figure 2E in [3].

b. Figure $2 \mathrm{a}$ in [1] is the same as Figure $6 \mathrm{a}$ in [2] and Figure $2 \mathrm{H}$ in [3], but rotated.

The authors apologize for these errors and agree to the retraction of the article. The author's institution investigated our concerns and concluded that these errors were not the result of academic misconduct. The article is being retracted with the agreement of the journal and the editorial board due to concerns regarding the reliability of the data.

\section{References}

[1] J. Zhao, L. Hu, J. Liu, N. Gong, and L. Chen, "The Effects of Cytokines in Adipose Stem Cell-Conditioned Medium on the Migration and Proliferation of Skin Fibroblasts In Vitro," BioMed Research International, vol. 2013, Article ID 578479, 11 pages, 2013.

[2] L. Hu, J. Hu, J. Zhao et al., "Side-by-Side Comparison of the Biological Characteristics of Human Umbilical Cord and Adipose Tissue-Derived Mesenchymal Stem Cells," BioMed Research International, vol. 2013, Article ID 438243, 12 pages, 2013.
[3] L. Hu, J. Zhao, J. Liu, N. Gong, and L. Chen, "Effects of adipose stem cell-conditioned medium on the migration of vascular endothelial cells, fibroblasts and keratinocytes," Experimental and Therapeutic Medicine, vol. 5, no. 3, pp. 701-706, 2013.

[4] Z. Jia-jia, L. Hu, L. Jia-rong, G. Ni-ya, and C. Li-li, "Adipose stem cell-derived growth factors and proliferation of oral mucosa fibroblasts," Journal of Clinical Rehabilitative Tissue Engineering Research, vol. 17, no. 32, pp. 5778-5784, 2013.

[5] J. Hu, L. Huiyu, and O. Weixiang, Isolation, Characterization and Induced Differentiation of Human Umbilical Cord Wharton's Jelly-derived Mesenchymal Stem Cells, CNKI, 2012, http://en.cnki.com.cn/Article_en/CJFDTOTALTJYX201205006.htm. 